\title{
Thermal cycling: impact on bentonite permeability
}

\author{
S.G. ZIHMS ${ }^{\#}$ AND J.F. HARRINGTON ${ }^{*}$
}

British Geological Survey, Transport Properties Research Laboratory, Nicker Hill, Keyworth NG12 5GG, UK

[Received 10 October 2014; Accepted 17 June 2015; Associate Editor: Katherine Morris]

\section{ABSTRACT}

Due to its favourable properties, in particular, low permeability and swelling capacity, bentonite has been favoured as an engineered-barrier and backfill material for the geological storage of radioactive waste. To ensure its safe long-term performance it is important to understand any changes in these properties when the material is subject to heat-emitting waste. As such, this study investigates the hydraulic response of bentonite under multi-step thermal loading subject to a constant-volume boundary condition, to represent a barrier system used in a crystalline or other hard-rock host rock. The experimental set up allows continuous measurement of the hydraulic and mechanical responses during each phase of the thermal cycle. After the initial hydration of the bentonite, the temperature was raised in $20^{\circ} \mathrm{C}$ increments from 20 to $80^{\circ} \mathrm{C}$ followed by a final step to reach $120^{\circ} \mathrm{C}$. Each temperature was held constant for at least $7-10$ days to allow the hydraulic transients to equilibrate. The data suggest that the permeability of bentonite appears to be sensitive to changes in temperature which may extend beyond those explained by simple changes in water viscosity. However, permeability may be boundary-condition dependent and this should be considered when designing experiments or applying these results to other repository host rocks. Either way, the magnitude of the change in permeability observed in this study is minor and its impact on the hydraulic performance of the barrier is negligible.

KEYWORDS: bentonite, permeability, thermal cycling, temperature, hydraulic.

\section{Introduction}

In the geological disposal of radioactive waste, heat emission from high-level waste can lead to a significant thermal gradient within the host-rock formation and engineered barrier system (Cui et al., 2009; François et al., 2009; Chen et al., 2011; Monfared et al., 2012; Cui and Tang, 2013; Li, 2013). Bentonite has been proposed in most repository designs as a barrier-system material,

*E-mail: jfha@bgs.ac.uk

${ }^{\#}$ Current Address: The Institute for Petroleum

Engineering, Heriot-Watt University, Edinburgh

EH14 4AS, UK

DOI: 10.1180/minmag.2015.079.6.29 due to its favourable characteristics, such as its low permeability and large swelling capacity (Pusch, 2002; Wersin et al., 2007; Gens et al., 2013). Due to the proximity of the engineered barrier to the waste it is important to understand if and how exposure to elevated temperature affects the barrier performance and hence its safety function. Exposure to elevated temperatures affects the volumetric response and its stress state (Romero et al., 2001; Gens et al., 2013; Romero et al., 2013), which in turn affects the hydraulic response of clays (Cho et al., 1999). Due to their very low permeabilities, clays can be considered in an undrained or nearly undrained condition, which is important when considering its short-term response (Horseman et al., 1996). Villar and Lloret (2004) and Cho et al. (1998) found that bentonite permeability

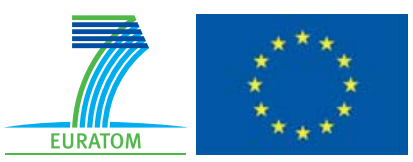

The publication of this research has been funded by the European Union's European Atomic Energy Community's (Euratom) Seventh Framework programme FP7 (2007-2013) under grant agreements $n^{\circ} 249396$, SecIGD, and $n^{\circ} 323260$, SeclGD2. 
increases slightly with temperature, which they attribute to the decrease in water viscosity. Most studies perform hydraulic testing after exposure to a temperature which represents only one time point in the thermal history of the sample. This study uses continuous monitoring of hydraulic properties to understand the behaviour of the bentonite during heating and cooling, as well as at stable temperature to delineate both transient and steady-state hydraulic responses. Data from this study will aid our understanding of bentonite performance during the thermal phase of repository evolution.

\section{Material and methods}

\section{Experimental set up}

The experiment described here was carried out using a custom-designed constant-volume cell (Harrington and Horseman, 2003). The constant volume radial flow (CVRF) consists of: (1) a thickwalled stainless steel pressure vessel; (2) a fluidinjection system; (3) an independent backpressure system; (4) five total stress sensors to measure radial and axial stress; (5) a pressure transducer; and (6) a logging system. The pressure vessel (Fig. 1a, b) comprises a stainless steel, dual-closure, tubular vessel the end-closures of which are secured by 12 high-tensile cap screws that can also apply a small pre-stress to the specimen if required. The position of the stress sensors and pressure transducer are shown in Fig. 1b,c. The pressure and flow rate of test fluid is controlled using two ISCO Teledyne260 , Series D pumps, operated by an ISCO pump controller. These units have an RS323 serial port, which allows volume, flow rate and pressure data from each pump to be transmitted to a bespoke logging system. Additional parameters (stress, temperature and porewater pressure) are logged simultaneously by the same system and the typical acquisition rate is one scan every $2 \mathrm{~min}$. All stress and pore-pressure sensors were calibrated against known laboratory standards by applying incremental steps in pressure, from atmospheric pressure to a pre-determined maximum value. This was followed by a descending history to quantify hysteresis. The calibration steps were repeated for different temperature values used during testing to allow for apparatus and sensor compliance. These data were used to develop a bi-quadratic calibration function for each sensor.

As shown in Fig. 1d,e, the CVRF is placed inside an oven (BINDER GmbH, Tuttlingen, Germany) with the two pumps and controller located outside the oven. This is to ensure that the pumps are not exposed to adversely high temperatures and thereby helps to minimize viscosity or volumetric effects on the experiment.

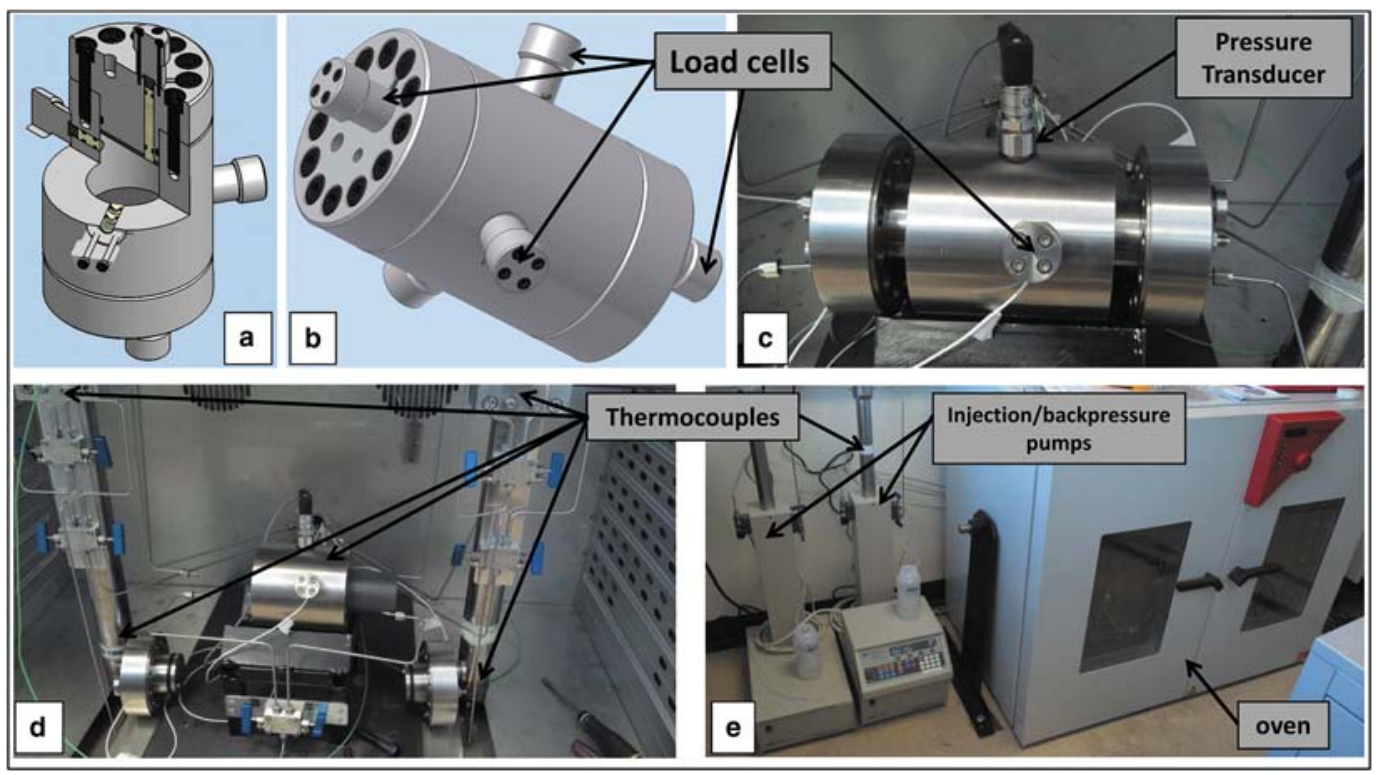

FIG. 1. Constant-volume cell design $(a-c)$ and experimental set-up $(d-e)$. 
TABLE 1. Geotechnical properties of bentonite before and after the hydraulic experiment.

\begin{tabular}{lccc}
\hline Geotechnical properties & & Pre-test & Post-test \\
\hline Saturation & $\%$ & 97 & 104 \\
Moisture content & & 26.7 & 29.1 \\
Bulk density & $\mathrm{kg} / \mathrm{m}^{3}$ & 1985 & 2014 \\
Dry density & & 1560 & 1560 \\
Porosity & $\%$ & 43.7 & 43.7 \\
Void ratio & & 0.776 & 0.776
\end{tabular}

\section{Sample preparation and properties}

Testing was carried out on a pre-compacted sample of MX-80 bentonite, which is the barrier material chosen for most high-level repository concepts. MX-80 bentonite is a fine-grained Na-bentonite from Wyoming (USA) which contains $\sim 90 \%$ montmorillonite. Blocks of pre-compacted bentonite were manufactured by Clay Technology AB (Lund, Sweden) by rapidly compacting bentonite granules in a mould under a stress applied in one-direction (Johannesson et al., 1995). It should be noted that these blocks are specifically manufactured to yield a large initial water saturation in order to minimize rehydration times. In this paper, results are presented from an experiment carried out on one cylindrical test specimen (60 $\mathrm{mm}$ in diameter and $60 \mathrm{~mm}$ long) sub-sampled from a larger bentonite block. Standard geotechnical properties for the sample pre- and posttest are shown in Table 1. The water content of the specimen was determined by weighing it pre-test and then oven-drying it post-test before weighing it again. The void ratio, porosity and degree of saturation are based on an average grain density for the bentonite of $2.77 \mathrm{mg} \mathrm{m}^{-3}$.

\section{Hydraulic testing under thermal loading}

The sample was hydrated with de-ionized water applied through both end-closure filters at an applied pressure of $1.0 \mathrm{MPa}$. Volumetric flow rates were controlled or monitored using a pair of ISCO-260, Series D, syringe pumps operated from

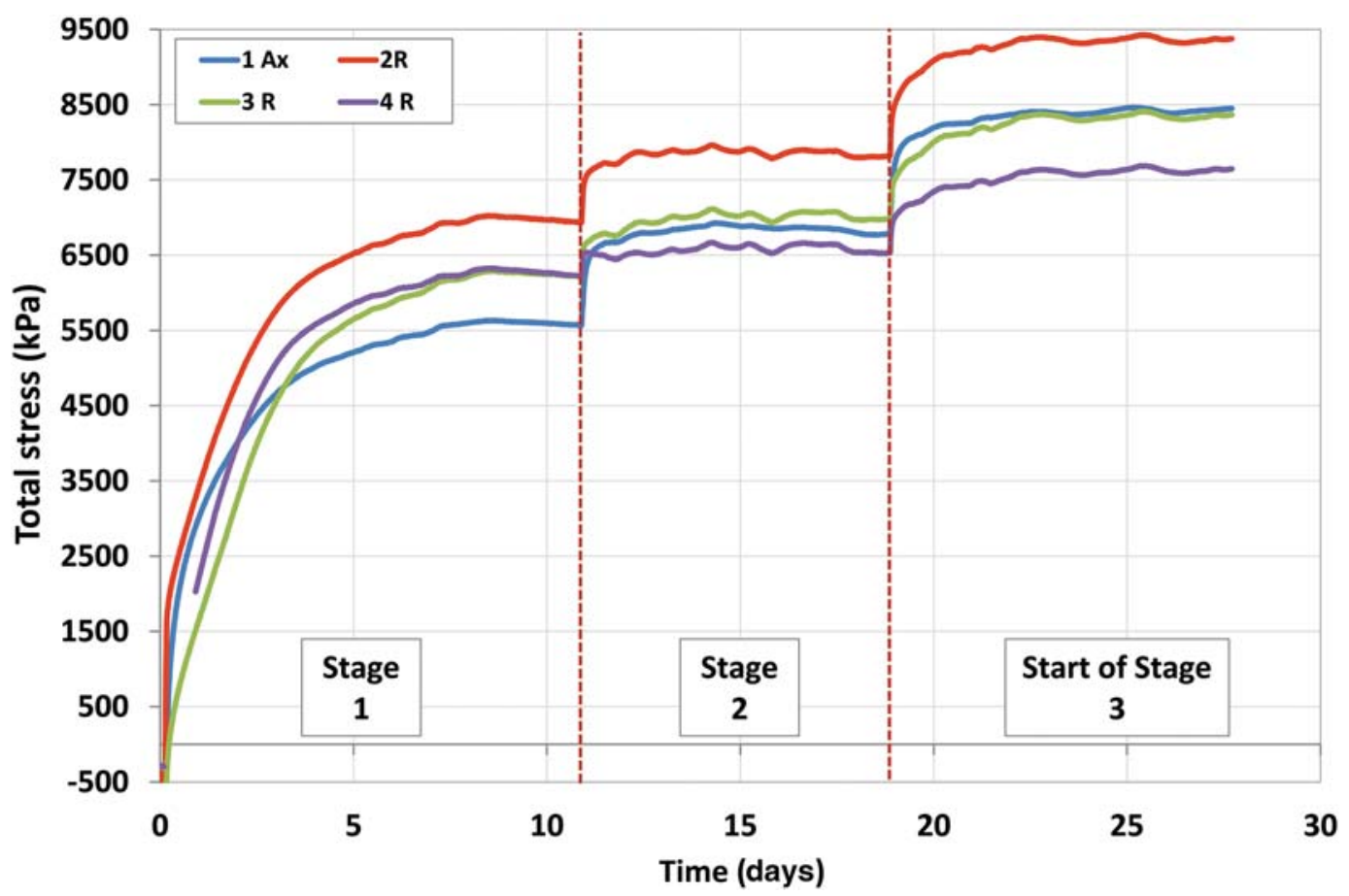

FIg. 2. Total stress evolution for test stages 1 to 3 for the bentonite at $20^{\circ} \mathrm{C}$. In stage 1 water pressure of $1 \mathrm{MPa}$ was applied to both ends of the sample. In stages 2 and 3 waterpressure in the injection pump was increased to $3 \mathrm{MPa}$ and $5 \mathrm{MPa}$, respectively. 
a single digital control unit. The position of each pump piston was determined by an optically encoded disc graduated in segments equivalent to a change in volume of $16.6 \mathrm{nl}$. Movement of the pump piston was controlled by a micro-processor which monitored and adjusted continuously the rate of rotation of the encoded disc using a DC-motor connected to the piston assembly via a geared worm drive. This allows each pump to operate in either constant-pressure or constant-flow modes. A programme written in LabVIEW $W^{\mathrm{TM}}$ elicited data from the pump at pre-set time intervals.

A backpressure of $1 \mathrm{MPa}$ was applied to the sample at all times. Once the stress stabilized and inflow was negligible, test stage 1 , the sample was considered to be hydrated and a pressure gradient was applied across the sample by increasing the injection pressure to 3 , stage 2 , and then $5 \mathrm{MPa}$, stage 3 . This pressure gradient was selected to yield a measurable flow, in a sensible timeframe while minimizing possible damage to the sample. While a differential pressure of $4 \mathrm{MPa}$ may appear relatively large, the samples were compacted mechanically (during fabrication) at a pressure of $37 \mathrm{MPa}$. Therefore significant consolidation of the sample due to the application of the hydraulic gradient seems unlikely.
After the stresses stabilized at the end of stage 3 as shown in Fig. 2, the sample was subjected to a stepped history of thermal loading. Temperature increments of 20 to $80^{\circ} \mathrm{C}$ and back to $20^{\circ} \mathrm{C}$ were imposed upon the sample. This temperature cycle was repeated twice to examine any potential change in bentonite behaviour. During the third thermal cycle the temperature was increased to $120^{\circ} \mathrm{C}$, at which point heating was stopped and the temperature decreased in a single step back to $25^{\circ} \mathrm{C}$. The test-stage settings are shown in Table 2 and the duration of each temperature exposure and related-flow response are shown in Fig. 3.

\section{Results}

The response of hydraulic flow through the bentonite for the duration of the experiment is shown in Fig. 3: the flow changed rapidly after each temperature step was applied. Flow settled to a new steady state value within $14 \mathrm{~h}$, however. Besides the spikes associated with temperature steps, the data show a fairly linear relationship between flow and temperature. Using the continuously measured flow data, the hydraulic conductivity $(K)$ and intrinsic

TABLE 2. Configuration of the individual testing stages.

\begin{tabular}{|c|c|c|c|c|}
\hline \multicolumn{2}{|c|}{ Testing stage } & \multirow{2}{*}{$\begin{array}{c}\begin{array}{c}\text { Injection pump pressure } \\
(\mathrm{MPa})\end{array} \\
1\end{array}$} & \multirow{2}{*}{$\begin{array}{c}\begin{array}{c}\text { Backpressure pump pressure } \\
(\mathrm{MPa})\end{array} \\
1\end{array}$} & \multirow{2}{*}{$\frac{\text { Average oven temperature }\left({ }^{\circ} \mathrm{C}\right)}{20}$} \\
\hline 1 & Hydration & & & \\
\hline 2 & Hydraulic testing & 3 & 1 & 20 \\
\hline 3 & Hydraulic testing & 5 & 1 & 20 \\
\hline \multirow[t]{2}{*}{4} & Stepped heating & 5 & 1 & 40 \\
\hline & & & & $\begin{array}{l}60 \\
80\end{array}$ \\
\hline \multirow[t]{3}{*}{5} & Stepped cooling & & & $\begin{array}{l}80 \\
60\end{array}$ \\
\hline & & & & 40 \\
\hline & & & & 20 \\
\hline \multirow[t]{3}{*}{6} & Stepped heating & & & 40 \\
\hline & & & & 60 \\
\hline & & & & 80 \\
\hline \multirow[t]{3}{*}{7} & Stepped cooling & & & 60 \\
\hline & & & & 40 \\
\hline & & & & 25 \\
\hline \multirow[t]{4}{*}{8} & Stepped heating & & & 40 \\
\hline & & & & 60 \\
\hline & & & & 80 \\
\hline & & & & 120 \\
\hline 9 & One-step cooling & & & 25 \\
\hline
\end{tabular}


THERMAL CYCLING: IMPACT ON BENTONITE PERMEABILITY

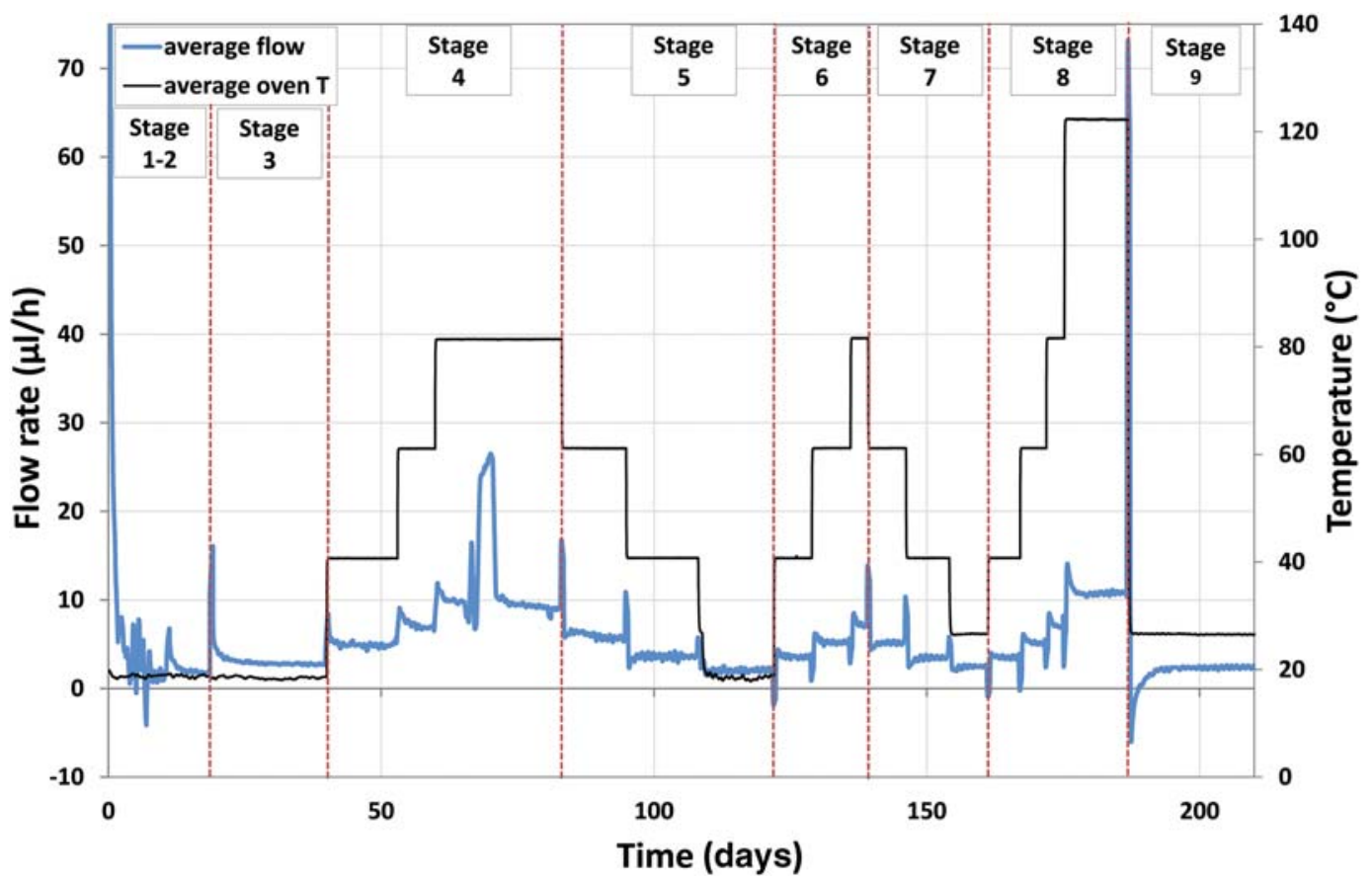

FIG. 3. Average measured flow through bentonite with different thermal loadings.

TABLE 3. Calculated hydraulic conductivity and permeability values of bentonite for the different testing stages.

\begin{tabular}{|c|c|c|c|c|c|}
\hline \multirow{2}{*}{ Testing stage } & \multirow{2}{*}{$\begin{array}{c}\text { Average oven } \\
\text { temperature }\left({ }^{\circ} \mathrm{C}\right)\end{array}$} & \multirow{2}{*}{$\begin{array}{l}\text { Uncorrected hydraulic } \\
\text { conductivity, } K(\mathrm{~m} / \mathrm{s}) \times 10^{-14}\end{array}$} & \multirow{2}{*}{ Error $\times 10^{-15}$} & \multicolumn{2}{|c|}{ Intrinsic permeability, $k_{\mathrm{i}}\left(\mathrm{m}^{2}\right) \times 10^{-21}$} \\
\hline & & & & uncorrected & corrected \\
\hline 3 & 18 & 4.6 & 0.5 & 4.8 & 4.8 \\
\hline \multirow[t]{3}{*}{4} & 40 & 7.3 & 7.9 & 7.6 & 4.9 \\
\hline & 60 & 10.6 & 8.2 & 11.0 & 5.1 \\
\hline & 80 & 14.4 & 7.4 & 15.2 & 5.4 \\
\hline \multirow[t]{3}{*}{5} & 60 & 9.0 & 18.3 & 9.4 & 4.4 \\
\hline & 40 & 5.3 & 9.8 & 5.5 & 3.6 \\
\hline & 18 & 2.8 & 7.5 & 2.9 & 2.9 \\
\hline \multirow[t]{3}{*}{6} & 40 & 4.9 & 14.3 & 5.1 & 3.3 \\
\hline & 60 & 7.6 & 8.5 & 7.9 & 3.7 \\
\hline & 80 & 11.1 & 26.2 & 11.7 & 4.2 \\
\hline \multirow{3}{*}{7} & 60 & 7.8 & 3.4 & 8.1 & 3.8 \\
\hline & 40 & 5.1 & 0.5 & 5.2 & 3.4 \\
\hline & 25 & 3.4 & 0.4 & 3.5 & 3.1 \\
\hline \multirow[t]{4}{*}{8} & 40 & 4.8 & 0.6 & 5.0 & 3.2 \\
\hline & 60 & 7.5 & 0.5 & 7.8 & 3.6 \\
\hline & 80 & 10.6 & 0.5 & 11.2 & 4.0 \\
\hline & 120 & 17.3 & 3.7 & 18.8 & 5.3 \\
\hline 9 & 25 & 3.3 & 0.1 & 3.3 & 3.0 \\
\hline
\end{tabular}


permeability $\left(k_{i}\right)$ for each stable temperature phase were calculated using equations 1 and 2 .

$$
K=\frac{Q}{A} \times \frac{d x}{d h}
$$

where $K$ is the hydraulic conductivity $(\mathrm{m} / \mathrm{s}), Q$ is the volumetric flow $\left(\mathrm{m}^{3} / \mathrm{s}\right), A$ is the cross-sectional area of the sample $\left(\mathrm{m}^{2}\right), d x$ is the length of the sample (m) and $d h$ is the pressure gradient across the sample. From the hydraulic conductivity the

a

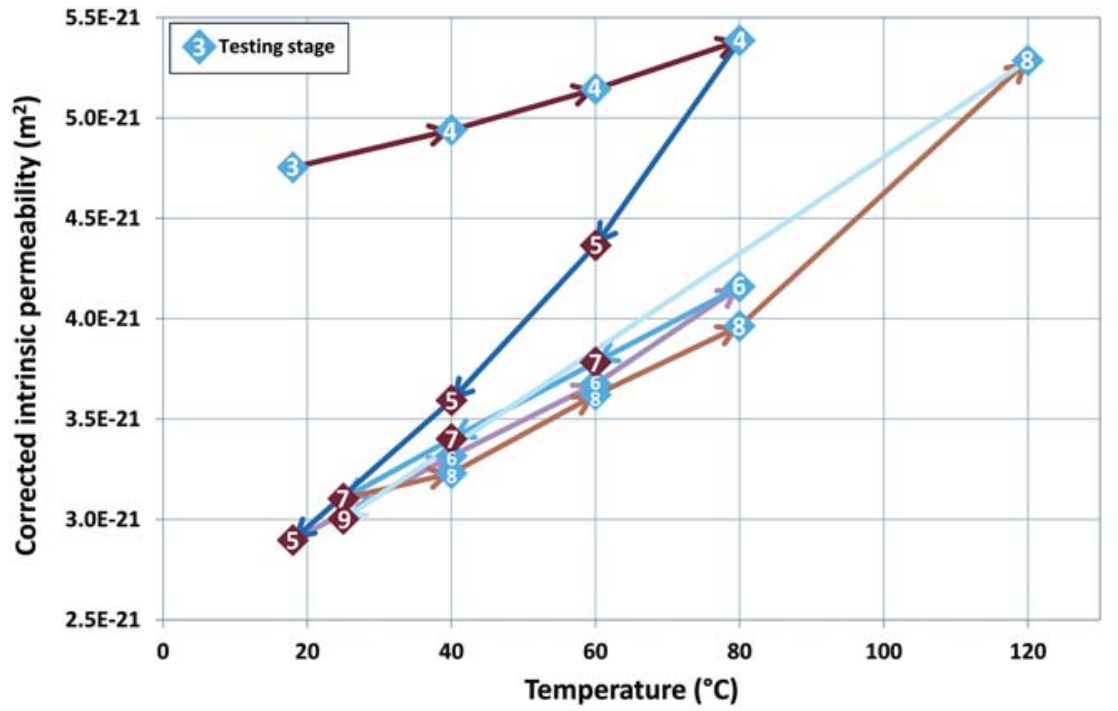

b

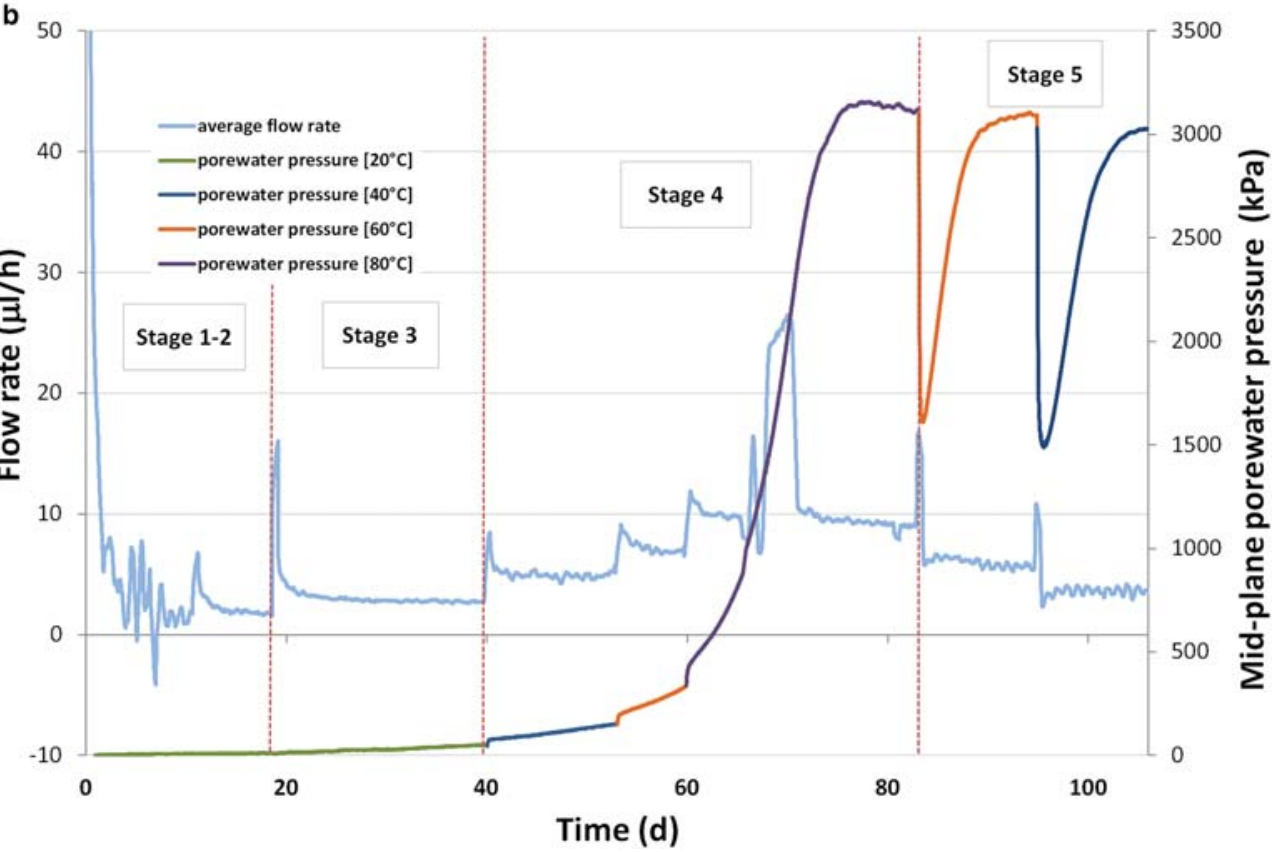

FIG. 4. (a) Evolution of intrinsic permeability (corrected for changes in water viscosity due to heating) during thermal cycling. (b) Development of porewater pressure (measured at the mid-plane of the sample) during the initial thermal cycle. 
intrinsic permeability, $k_{i}$, can be calculated:

$$
k_{i}=\frac{K \eta_{w}}{\rho_{w} g}
$$

where $\eta_{w}$ is the viscosity of water $(\mathrm{Pa} \cdot \mathrm{s}), \rho_{w}$ is the density of water $\left(\mathrm{kg} / \mathrm{m}^{3}\right)$ and $g$ is the acceleration due to gravity $\left(\mathrm{m} / \mathrm{s}^{2}\right)$. When correcting the intrinsic permeability for changes in water viscosity and density it is important to remember that the values for $\eta_{w}$ and $\rho_{w}$ are no longer constant.

The values for each stable temperature phase are given in Table 3. The corrected values show the intrinsic permeability corrected for a change in water viscosity with temperature. When these values are plotted against temperature, Fig. $4 a$, several observations can be made. Significant hysteresis was observed during the first thermal loading cycle (stages 4-5). This may stem from incomplete hydration during this phase of testing, as observed by an apparent lag in pore-pressure development during stages 1-4 (Fig. 4b). In contrast to the stress data presented in Fig. 2, this would suggest that measurement of stress alone may be a poor proxy for the determination of hydraulic equilibrium in bentonite. However the cause of the 'spikes' in flow observed around days 64 and 67 remains unclear. Following stage 5, the degree of hysteresis for successive thermal loads reduces significantly as the sample tracks a repeatable hysteresis loop. The underlying sensitivity of permeability to changes in temperature can be seen clearly within the data. Even though the data are corrected for temperature-dependent viscosity changes, permeability is observed to increase six-fold between 20 and $120^{\circ} \mathrm{C}$. While this represents a significant change in permeability, its impact on the hydraulic performance of the barrier is negligible. It is worth noting that at the end of each temperature cycle (heating + cooling, stages 6-9) permeability returns to its original value observed at the end of stage 5. This remains the case even when temperature increased to $120^{\circ} \mathrm{C}$. The exact cause of the initial hysteresis during the first thermal cycle, test stages 4-5, remains unclear but may relate to time-dependent effects related to progressive homogenization of the clay as suggested by the mid-plane porewater pressure response (Fig. 4b).

\section{Discussion}

Repository safety cases consider a much longer timeframe $(\sim 1000 \mathrm{y})$ for the initial heating phase of the bentonite than that taken into account in this study (Bucher and Müller-Vonmoos, 1989; Wersin et al., 2007). However, recent work by Harrington et al. (2014) on samples of bentonite from the Canister Retrieval Test performed at the Äspö hard rock laboratory (Sweden) showed that bentonite permeability (tested at $20^{\circ} \mathrm{C}$ only) was unaffected even after prolonged exposure $(5 \mathrm{y})$ of the clay to temperatures of $80^{\circ} \mathrm{C}$. This observation combined with those from the present study suggest that significant degradation of the hydraulic performance of the barrier is unlikely up to temperatures of $80^{\circ} \mathrm{C}$. However, the change in permeability of the bentonite with increasing temperature goes beyond that which can be explained by simple changes in water viscosity, which suggests that other factors may influence hydraulic behaviour during heating. Indeed, Villar and Lloret (2004) suggested that changes in the microfabric of the clay could explain the additional increase in permeability and that these structural changes may be reversible. However, thermal contraction of the clay matrix in the constant-volume cell used within this study (combined with small-scale expansion of the steel when heated) could result in an apparent increase in permeability as the clay contracts away from the vessel wall, i.e. resulting in an enhanced permeability along the sample circumference. While this result suggests that the permeability observed may be sensitive to the test-boundary conditions (i.e. geometry dependent), the apparatus used in this study provides a good representation of the likely behaviour of a repository sited in crystalline or other hard-rock geology. If thermal contraction of bentonite does occur, matrix permeability is likely to decrease as temperature rises. However, the increase in viscosity may offset some of these changes. To explore these relationships additional work is required to address the changes in volume during thermal contraction and its impact on permeability.

\section{Conclusion}

The permeability of bentonite appears to be sensitive to changes in temperature which may extend beyond those that can be explained by simple changes in water viscosity. Increases in permeability were observed during the course of three thermal loading cycles which exhibited similar hysteresis behaviour, with no permanent alteration of permeability observed. While permeability is sensitive to thermal load, and in part the 
test boundary conditions, its impact on the hydraulic performance of the barrier is negligible. As such, these results are of direct relevance to a repository sited in crystalline or other hard rock geology and represent a conservative estimate of permeability change for use within a safety case.

\section{Acknowledgements}

This study has been funded by EPSRC as part of the Systems Approach For Engineered (SAFE) Barriers project. The authors thank Dr Noy of the British Geological Survey for the development of the biquadratic functions required for the calibration of the sensors. This paper is published with the permission of the Director, British Geological Survey (NERC).

\section{References}

Bucher, F., Müller-Vonmoos, M. (1989) Bentonite as containment barrier for the disposal of highly radioactive wastes. Applied Clay Science, 4, 157-177.

Chen, G.J., Sillen, X., Verstricht, J. and Li, X.L. (2011) ATLAS III in situ heating test in boom clay: Field data, observation and interpretation. Computers and Geotechnics, 38, 683-696.

Cho, W.J., Lee, J.O. and Chun, K.S. (1999) The temperature effects on hydraulic conductivity of compacted bentonite. Applied Clay Science, 14, $47-58$.

Cui, Y.-J. and Tang, A.M. (2013) On the chemo-thermohydro-mechanical behaviour of geological and engineered barriers. Journal of Rock Mechanics and Geotechnical Engineering, 5, 169-178.

Cui, Y.J., Delage, P., Le, T.T., Li, X.L. and Tang, A.M. (2009) Investigating the time-dependent behaviour of Boom clay under thermomechanical loading. Géotechnique, 59, 319-329.

François, B., Laloui, L. and Laurent, C. (2009) Thermohydro-mechanical simulation of ATLAS in situ large scale test in Boom Clay. Computers and Geotechnics, 36, 626-640.

Gens, A., Valleján, B., Zandarín, M.T. and Sánchez, M. (2013) Homogenization in clay barriers and seals: Two case studies. Journal of Rock Mechanics and Geotechnical Engineering, 5, 191-199.

Harrington, J.F., Volckaert, G. and Noy, D.J. (2014) Longterm impact of temperature on the hydraulic permeability of bentonite. Pp. 589-601 in: Clays in Natural and Engineered Barriers for Radioactive Waste Confinement (S. Norris, J. Bruno, M. Cathelineau, P. Delage, C. Fairhurst, E.C. Gaucher, E.H. Höhn, A. Kalinichev, P. Lalieux and P. Sellin, editors). Special Publications, 400, Geological Society, London.

Horseman, S., Higgo, J.J.W., Alexander, J. and Harrington, J.F. (1996) Water, Gas and Solute Movement through Argillaceous Media. Report No. CC-96/1 to OECD/NEA Working Group on Measurement and Physical Understanding of Groundwater Flow through Argillaceous Media. Nuclear Energy Agency, OECD, Paris.

Johannesson, L.E., Boergesson, L. and Sanden, T. (1995) Compaction of bentonite blocks. Development of technique for industrial production of blocks which are manageable by man, Sweden. Svensk Kärnbränslehantering $\mathrm{AB}$ (SKB) Technical Report TR-95-19.

Li, X. (2013) TIMODAZ: A successful international cooperation project to investigate the thermal impact on the EDZ around a radioactive waste disposal in clay host rocks. Journal of Rock Mechanics and Geotechnical Engineering, 5, 231-242.

Monfared, M., Sulem, J., Delage, P. and Mohajerani, M. (2012) On the THM behaviour of a sheared Boom clay sample: Application to the behaviour and sealing properties of the EDZ. Engineering Geology, 124, 47-58.

Pusch, R. (2002) The buffer and backfill handbook, Part 1: Definitions, basic relationships, and laboratory methods. Svensk Kärnbränslehantering $\mathrm{AB}$ (SKB) Technical Report TR-02-20.

Romero, E., Gens, A. and Lloret, A. (2001) Temperature effects on the hydraulic behaviour of an unsaturated clay. Geotechnical and Geological Engineering, 19, 311-332.

Romero, E., Lima, A., Gens, A. and Vaunat, J. (2013) Determination of the thermal parameters of a clay from heating cell tests. 18th International Conference on Soil Mechanics and Geotechnical Engineering, Paris, France.

Villar, M.V. and Lloret, A. (2004) Influence of temperature on the hydro-mechanical behaviour of a compacted bentonite. Applied Clay Science, 26, 337-350.

Wersin, P., Johnson, L.H. and McKinley, I.G. (2007) Performance of the bentonite barrier at temperatures beyond $100^{\circ} \mathrm{C}$ : A critical review. Physics and Chemistry of the Earth, Parts $A / B / C, 32,780-788$. 